\title{
Estampas del deseo y del desear. Imágenes de moda en Argentina en las primeras décadas de 1900*
}

Gisela Paola Kaczan**

\begin{abstract}
Resumen
El trabajo se propone indagar sobre el rol referencial de las fotografías de moda en el contexto argentino, en las primeras décadas de 1900. Estas imágenes no sólo difundían las transformaciones estéticas de un sector en avance sino que, debido a su "aparente verosimilitud" con la realidad, fueron un estímulo para los comportamientos de la época interpretándolos como ejemplares que, a la vez, se tradujeron en modelos que pusieron en tensión los valores de virtud largamente defendidos. Mujeres de la alta sociedad, maniquíes y estrellas de cine conforman el catálogo de figuras.
\end{abstract}

Palabras clave: Fotografía de Moda, Modelos Controversiales, Mujeres de Sociedad, Maniquíes, Estrellas de Cine.

\footnotetext{
" Recebido para publicação em 11 de novembro de 2011, aceito em 19 de dezembro de 2012. Este trabajo resulta de la reelaboración de un capítulo de la Tesis doctoral Kaczan (2011:248-284).

** Diseñadora Industrial, Doctora en Historia. Investigadora del Consejo Nacional de Investigaciones Científicas y Técnicas (CONICET) y del Centro de Estudios Históricos, Arquitectónicos y Urbanos, Facultad de Arquitectura, Urbanismo y Diseño de la Universidad Nacional de Mar del Plata, Buenos Aires, Argentina. gisela.kaczan@gmail.com
}

cadernos pagu (41), julho-dezembro de 2013:121-157. 
Estampas del deseo y del desear

Prints of desire and to desire.

Fashion images in Argentina in the first decades of 1900

\begin{abstract}
The paper proposes to investigate the referential role of fashion photography in the argentine context, in the first two decades of 1900. Images that not only diffused aesthetic changes in the industry, to this "supposed verisimilitude" were a stimulus to behaviors interpreted as exemplary and, at the same time, translated models to put in tension virtue values long defended. High society women, mannequins and stars make up the figures catalog.
\end{abstract}

Key Words: Fashion Photography, Controversial Models, Society Woman, Mannequin, Movie Stars. 


\section{Introducción}

La fotografía no puede reproducir el encanto de los reflejos voluptuosos del terciopelo, de los efectos cromáticos de las sedas, pero nos da el concepto exacto de la línea, como característica de la estación. Por eso la mujer debería creer más en las fotografías que en los dibujos y si las que se mandan hacer un vestido nuevo pudieran probárselo y hacérselo fotografiar antes de elegirlo definitivamente no habría desilusiones. ${ }^{1}$

Hacia los primeros años del siglo XIX, los procesos de medios tonos revolucionaban las formas de plasmar imágenes diversas del mundo. Gracias a los adelantos técnicos ya era posible imprimir imágenes fotográficas $y$, con ello, retratos artísticos de modelos, también conocidas como mannequin vivants, que comenzaron a diseminarse en la cultura visual. En sus inicios, el itinerario de exposición se resolvía en círculos minoritarios. Ya avanzado el siglo XX, la prensa ilustrada fue un dispositivo activo para una difusión de amplio alcance.

Derivado de este marco, se pretende indagar el rol que tuvieron estas imágenes, entendiendo que no sólo eran vehículos para dar a conocer las transformaciones tipológicas y tecnológicas de cada temporada y para continuar con el crecimiento de un sector industrial cada vez más redituable económicamente. El presente trabajo se propone examinar dichas imágenes como fenómenos socioculturales de carácter visual para canalizar la convivencia de disposiciones de género, en ocasiones contradictorias, acontecidas en las dos primeras décadas del siglo $\mathrm{XX}$. Por un lado, estas disposiciones provocaban la emulación de apariencias y comportamientos habilitados socialmente $y$, por otro, tuvieron incidencia en la traducción de modelos que tensionaban valores de "virtud" largamente sostenidos. El trabajo

${ }^{1}$ La ilusión en la moda. Revista Caras y Caretas. Buenos Aires, Año XXVIII, N ${ }^{\circ}$ 1116, 21 de noviembre 1925. 
pretende transitar sobre las oscilaciones entre el mostrar seres idealizados por su perfección y/o su adhesión a patrones de cierta estabilidad social y seres deseados por su capacidad de disolución de fórmulas ejemplares.

En respuesta a dicho planteamiento, se profundizará en las características de los procesos de producción y en las potenciales formas de recepción, áreas que articulan los atributos compositivos y simbólicos de las imágenes. De allí que el contexto de observación se ubique en las revistas ilustradas, las que por sus características temáticas habrían sido leídas por un público más o menos diverso, situación que permite hallar un espectro heterogéneo de datos relevantes sobre la información de la época (Traversa, 1997). Con este propósito, y de manera particular, se ha analizado la revista Caras y Caretas impresa en Buenos Aires, capital argentina, apoyando el análisis de esta información con ejemplares de otros títulos nacionales. Asimismo, se han consultado ejemplares de la prensa internacional para verificar cómo los modelos respondían, en varios aspectos, a tendencias de gran alcance. ${ }^{2}$

\section{Sobre la fotografía}

Como intermitencias arbitrarias de lo vivido, las imágenes fotográficas establecen un lenguaje dentro de la cultura visual con

${ }^{2}$ La indagación propuesta es un extracto del proyecto de Tesis doctoral Kaczan (2011). De la revista Caras y Caretas se han revisado alrededor de 20 ejemplares por año -en el lapso de noviembre a marzo- entre las décadas del 1900 al 1930, un total de 600 ejemplares. Se ha confrontado con El Hogar, Fray Mocho, Plus Ultra, Miryam y PBT de Buenos Aires. Entre las revistas internacionales se ha visto Vie D'Italia e dell'America Latina, Milan, Natura ed Arte, Ressegna quindicinale illustrata, italiana e straniera di Scienze, Lettere ed Arti. Milan, La Ilustración Española. Madrid, La Esfera, Madrid. Blanco y Negro, España. En relación con las revistas de moda se han revisado La Mode Illustrée. Journal de la famille, París, Fémina, París, La Moda Elegante, España, La Estación. Periódico para señoras, Madrid, Mele, Italia.-El Salón de la moda, Barcelona, Harper's Bazaar, New York, Vogue, Francia. 
códigos particulares de comunicación. Detienen un intervalo del transcurrir para perpetuarlo en el futuro y se comportan como testimonios controversiales de la realidad. Una imagen fotográfica "no es más que un soporte con un aglomerado de manchas de diferentes tonos cromáticos o de diferentes densidades de gris, vacíos a priori de todo contenido semántico", señala Joan Fontcuberta pero, al mismo tiempo, "debido a ciertos procesos cognoscitivos y culturales adquieren para nosotros un determinado sentido" (Fontcuberta, 1990:10).

Consabido es que la fotografía, como imagen analógica, requiere de la coordinación de sistemas mecánicos, ópticos y químicos para reproducir aquello que está frente a la cámara. Esto habría sido, durante mucho tiempo, argumento para considerarla como un mecanismo de registro que reproducía fiel $e$ imparcialmente la vida social (Freund, 1993). La idea vendría respaldada por el hecho de que los propios objetos dejan una huella en la plancha fotográfica cuando se exponen a la luz, entonces, a través de la cámara, se objetivaría la realidad y la imagen sería su mimesis. En este sentido, la fotografía sería catalogada como signo icónico o índex, es decir, el significante tendría una relación de similitud con su referente.

Sin embargo, esto no concluye la discusión, todo lo contrario, ya que no se puede obviar que el registro del mundo es, necesariamente sesgado. Se concilian diferentes puntos de vista: la subjetividad del fotógrafo, cargado de un acervo personal que lo une a los enclaves de su contexto, los cuales condicionan las impresiones a retratar junto a las estrategias técnico-compositivas para hacerlo; el cliente o comitente supone requerimientos ligados a quienes la publican, en el caso de que la imagen tenga circulación editorial. Es ineludible vislumbrar el proceso de decodificación que realiza el observador y que puede movilizar y renovar los sentidos del mensaje (Dubois, 1994; Kossoy, 2001; Moxey, 2009). Se comprende que la composición fotográfica está distante de objetivar la realidad, más bien, posee la habilidad de concertar visiones, incluso inéditas, de lo cotidiano y descubrir 
aspectos intangibles de la cultura donde circuló. Este aspecto es el que interesa desandar.

\section{La moda en celuloide}

Focalizando en la fotografía de moda, la historia del vestir ha dado a conocer que habría sido empleada inicialmente por el modisto inglés de alta costura Charles Worth en la década de $1850 .^{3} \mathrm{Su}$ objetivo era mostrar los vestidos de su creación y en vez de emplear los maniquíes de madera, convocó a mujeres para hacerlo. La reproducción era limitada, la exposición se hacía para grupos selectos y no tenía mayor difusión. La aprobación de la técnica se dilató, algunos diseñadores desconfiaban del mecanismo porque, según ellos, se revelaba demasiada información y esto alentaba las copias ilegítimas (Peres, 2008).

Desde sus comienzos y hasta finales del siglo XIX, la fotografía de moda aducía algunas similitudes con el género del retrato. La escenificación, los telones de fondo pintados, los objetos contiguos, las poses que adoptaban las modelos, se identificaban con el léxico visual de la carte de visite y las tomas se adherían a sus convenciones. ${ }^{4}$ En muchos sentidos, los retratos pudieron ser considerados como declaraciones de moda, porque la protagonista casi siempre vestía sus mejores trajes y lucía los peinados de actualidad (Warren, 2006). Pero, esas fotografías, al principio, eran vistas por los familiares y amigos, no tenían ningún tipo de propósito comercial. Cuando estas imágenes comenzaron

\footnotetext{
3 Para mayor información sobre el modisto puede verse http://www.metmuseum.org/toah/hd/wrth/hd_wrth.htm

4 Esta parece ser una herencia recurrente. Es oportuno mencionar que durante la segunda mitad del siglo XIX, cuando se inicia la práctica de los retratos fotográficos elaborados en estudio, este género adoptaría las convenciones existentes del retrato pictórico. Sobre estas vinculaciones pueden verse especialmente Burke (2005), Freund (1993).
} 
a circular en la prensa, el fin era trascender un personaje selecto al conocimiento público. ${ }^{5}$

Las revistas ilustradas argentinas presentaron entre sus páginas una serie de "catálogos faciales" para mostrarlos a mujeres, en su mayoría a las esposas de los hombres pertenecientes a las clases privilegiadas del país. Eran retratos en el estudio del fotógrafo, con títulos del tipo "Nuestras damas", "Distinguidas Señoritas" o "Bellezas Argentinas". ${ }^{6}$ Esto implicaba una especie de "recordatorio social" en relación con el grupo de conocidos ya que "las fotografías públicas capturan una pose que puede constituirse en un discurso sobre aquello que quiere construirse socialmente" (Lobato, 2004:242). La presencia en este ámbito se sumaba a los rituales de sociabilidad de las retratadas para conjugar la exaltación individual y la admiración pública. Los protocolos de presentación sistematizaban una construcción estilística recurrente en la que el lenguaje corporal y la forma de vestir codificaban el semblante de una mujer propia de la high.

Había, también, páginas artísticas destinadas a difundir las imágenes de actrices de teatro o cantantes de ópera. Sus pretensiones eran otras, ellas acudían al estudio del fotógrafo como un modo de autopromoción comercial, empleadas con frecuencia al presentar un nuevo espectáculo. La apariencia se componía a través de fórmulas inmanentes del vestuario teatral y, en algunos casos, eran vestidas por algún modisto afamado para acrecentar su distinción (Imagen 1).

Puede decirse que artistas y mujeres de la alta sociedad habrían sido modelos precedentes de la fotografía de moda. En particular, los tipos de feminidad propuestos por estas últimas estaban más cerca de perpetuar un lugar de honorabilidad,

\footnotetext{
5 Alrededor de la década de 1880 se resuelve la técnica de la fotorreproducción que permite el facsímil de originales de diversa procedencia (como los negativos) sobre matrices para cualquier método de grabado o sistema de estampación. Así, se dio la posibilidad de editar fotografías en láminas, cartas postales e imprimir páginas de revistas ilustradas. Cfr. Coronado (2000:1-7); Tell, (2009:141-164)

6 Para profundizar sobre esta temática, se puede consultar Ariza (2011).
} 
Estampas del deseo y del desear

otorgado más por pertenecer a una tradición familiar y por llevar un apellido como prueba de linaje, que por dar idea de vanguardia. Provocaban la emulación de las lectoras por ser referentes de distinción aristocrática, tan mentada en los epígrafes, aunque la idea de aristocracia fuera puramente simbólica.
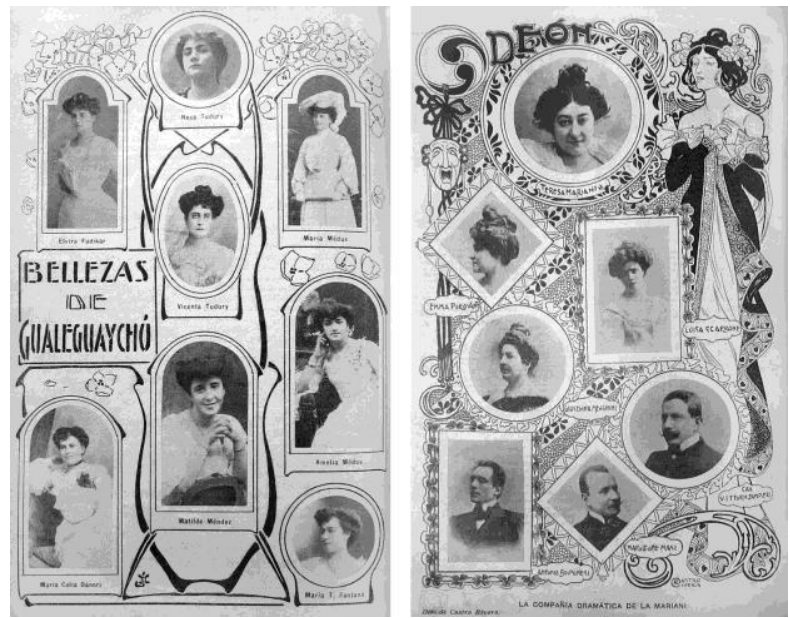

Imagen 1: Bellezas de Gualeguaychú. Revista Caras y Caretas, Buenos Aires, año VII, no 275, 9 de enero 1904/Odeón. Revista Caras y Caretas año $\mathrm{V}, \mathrm{n}^{\circ}$ 182, 29 de marzo 1902.

Desde la inauguración de las revistas ilustradas, las secciones informales para hablar de modas incorporaron imágenes que, en muchos casos, eran grabados que imitaban fotografías, algunos prefabricados como clisés estándar. ${ }^{7}$ La Imagen 2 muestra

\footnotetext{
7 Cuando hizo su aparición la técnica fotográfica y, con ella, la posibilidad de retratar numerosas escenas de la vida social, algunos grabadores la tomaron como referente, copiaron los rostros de retratos y reprodujeron los cuerpos al modo de tomas de estudio. En consecuencia, era frecuente que la modelo se ubicara delante de un fondo de tela pintada, junto con elementos mobiliarios de la época, como sillas, mesas o floreros. En muchas ocasiones, los elementos escenográficos operaban como sostén de los retratados. Los tiempos de exposición, al principio, eran medianamente prolongados, (1/15 segundos
} 
un ejemplo de esta situación, ya que el mismo grabado aparece en dos contextos diferentes - en una sección de modas y en un aviso de cochería- en años consecutivos (Imagen 2).
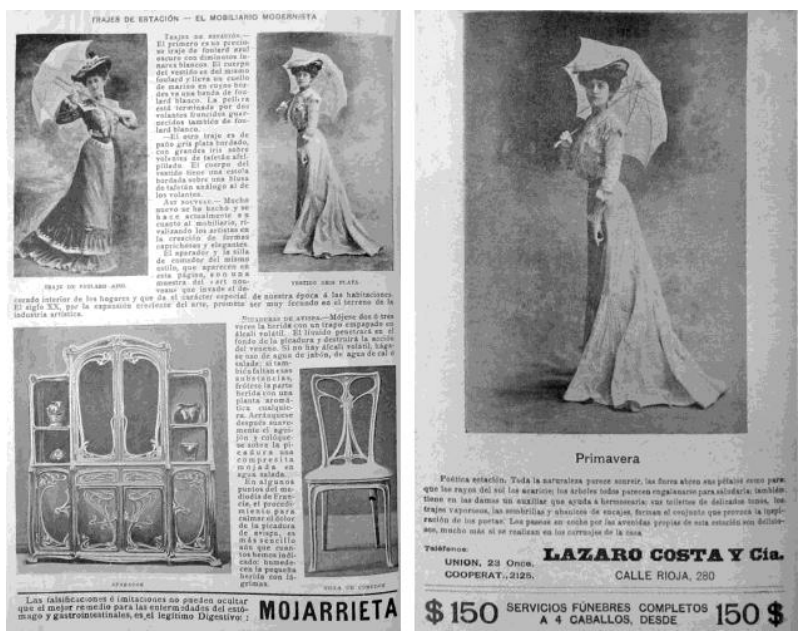

Imagen 2: Trajes de estación. Revista Caras y Caretas, Buenos Aires, Año V, No 182, 29 de marzo 1902/Aviso publicitario de Lázaro Costa y Cía., en Revista Caras y Caretas, Buenos Aires, Año VI, N 250, 26 de Septiembre 1903.

Los clisés se confeccionaban en Europa, en las fábricas donde se formaban los tipos móviles para las tipografías y, de allí, se exportaban a diferentes imprentas. Resulta poco probable que los grabadores llegaran a conocer siquiera a alguna de sus modelos, en ocasiones eran producto de su invención. Se infiere que la circulación de imágenes europeas fortalecía los procesos de copia por parte de los grupos que decidían las estéticas de la moda en Argentina.

aproximadamente) debido a la poca sensibilidad de la película fotográfica, por lo tanto, era comprometido mantenerse completamente inmóvil para que la cámara no registrase el movimiento. 
En paralelo, circuló un tipo de representación muy diferente a los retratos, que por sus características podría ser apuntada como fotografía de costumbre ${ }^{8}$ más espontánea y asociada con las crónicas mundanas. En este soporte se plasmaban escenas de eventos "chic" y se daba cuenta de las toilettes que se vestían (Imagen 3). ${ }^{9}$ Los encargados de las casas de alta costura enviaban a sus maniquíes - muchachas que desfilaban en los departamentos de moda de los comercios - para que pasaran a formar parte del público. La intención era llamar la atención y ganarse la admiración de las concurrentes:

Monsieur Poiret y Monsieur Patou, galanes un poco fatigados, así como la pequeña Madame Jenny y la severa Madame Lanvin (...) se esfuerzan por enseñar elegancia a los metecos millonarios y analfabetos de Deauville. Y las mannequins destacadas de la "Maison" de Paris sancta-sanctorum de la Rue de la Paix o de la Place Vendôme, luchan sobre el hipódromo (...) posan y giran ante el público de las tribunas con movimientos innecesarios, con actitudes injustificadas, buscando el "efecto." 10

\footnotetext{
8 Se toma esta clasificación de Luis Príamo (1999:275-299), quien postula la relación entre vida privada y fotografía a través de tres tipos de imágenes. En primer lugar, los retratos de estudio, en segundo lugar, las fotografías tomadas fuera del estudio del fotógrafo, por último las fotos de costumbres, realizadas por los antiguos documentalistas primero y los fotógrafos de prensa, más tarde.

9 Era usual que los directivos de medios gráficos emplearan sus propios fotógrafos para cubrir los eventos, pero también que complementaran esta información con fotos adquiridas de las agencias locales, europeas o norteamericanas. Esto permitía el seguimiento de las novedades en el orden internacional. Incluso, a veces, se realizaban fotomontajes de figuras sobre un escenario en el que nunca habían transitado.

${ }^{10}$ De Linares, Antonio Tout-Paris en Deauville... Revista La Esfera. Madrid, Año $\mathrm{XV}, \mathrm{N}^{\circ} 766,8$ de septiembre 1928.
} 

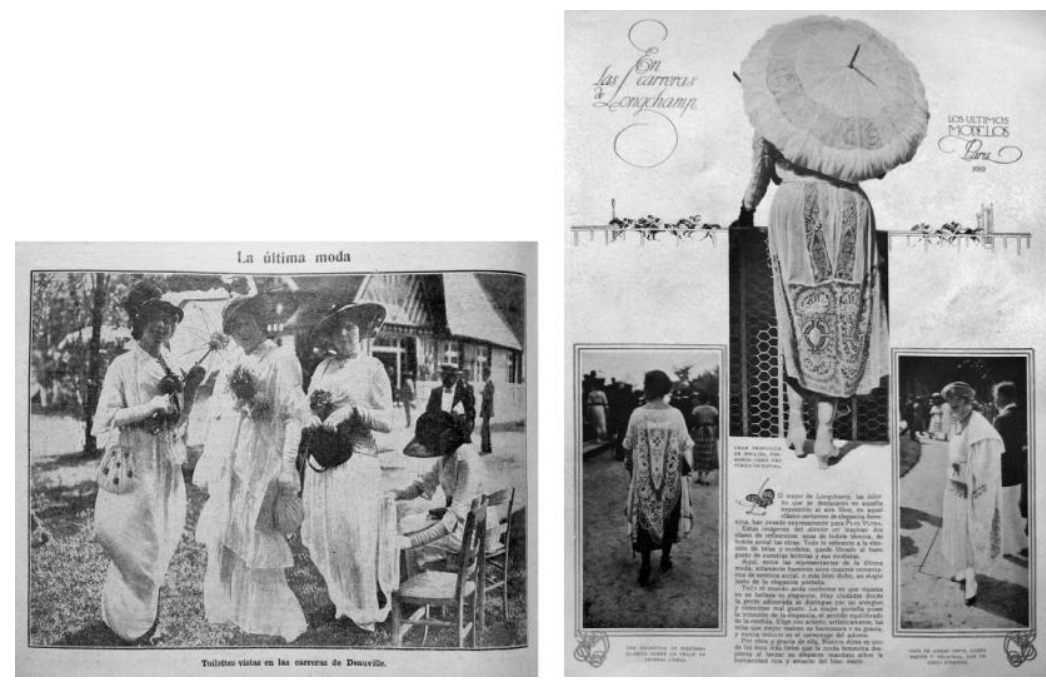

Imagen 3: La última moda. Revista Caras y Caretas, Buenos Aires, año XVI, n 782, 27 de septiembre 1913 / En las carreras de Longchamp. Los últimos modelos de París. Revista Plus Ultra, Buenos Aires, año IV, nº 41, septiembre 1919.

El itinerario por las revistas ilustradas demuestra que hacia mediados de 1910, las fotografías de moda se ubicaron en secciones femeninas independientes y con una frecuencia continuada. ${ }^{11}$ En general se destinaba una página completa para una o varias fotografías y cada revista ofrecía formatos particulares. Sin hacer hincapié en la variedad de diseños, se dirá que una mezcla de recursos gráficos se conjugaba para ensalzar las imágenes. Los epígrafes los proveían de descripciones más o menos completas de los vestidos o accesorios y revelaban la

\footnotetext{
${ }^{11}$ Las revistas de moda Harper's Bazaar, inaugurada en 1867 y Vogue lanzada por la editorial Condé Nast Publications en 1892, han sido las publicaciones que, desde principio del siglo XX, se han destacado en el mercado por la inclusión de fotografía de moda y la colaboración de fotógrafos renombrados en el género. La transformación más marcada se habría generado hacia la década de 1920 con la presencia de fotógrafos como Adolph de Meyer, Jean Edward Steichen, George Hoyningen-Huelne, Man Ray, entre otros.
} 
Estampas del deseo y del desear

identidad de los modistos afamados, tal como Worth, Drecoll, Poiret (Imagen 4). Cuando la autoría era anónima, recursos literarios como "bonita combinación lanzada por uno de los más afamados modistos neoyorkinos" 12 o "ha sido creado este modelo por una de las más famosas casas parisienses en el arte del bien vestir," completaban la descripción. ${ }^{13}$
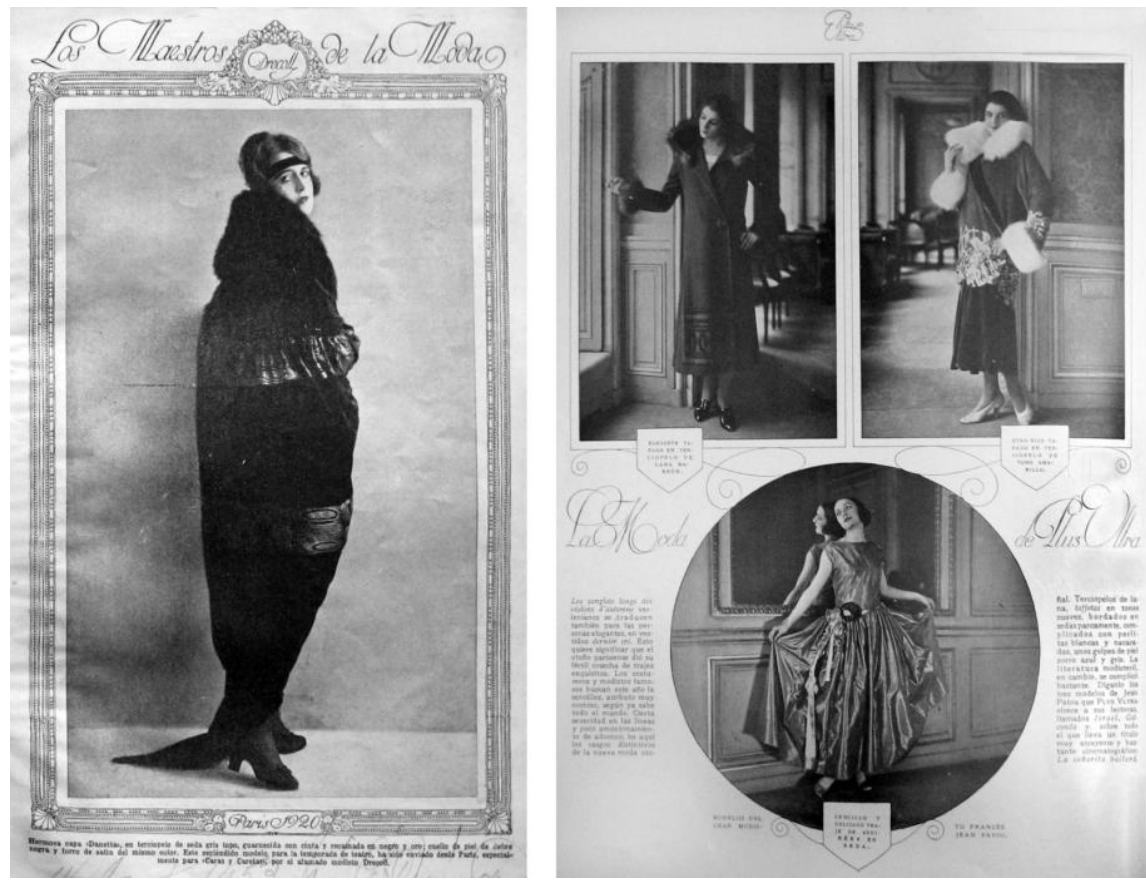

Imagen 4: Los maestros de la moda. Drecoll. Revista Caras y Caretas, Buenos Aires, Año XXIII, n 1121, 27 de marzo 1920 / La moda de Plus Ultra. Modelo del gran modisto Jean Patou. Revista Plus Ultra, Buenos Aires, Año VII, nº 91, noviembre 1923.

${ }^{12}$ Modelo íntimo. Revista Caras y Caretas. Buenos Aires, Año XXIX, № 1471, 11 de diciembre 1926.

${ }^{13}$ Revista El Hogar. Buenos Aires, Año XVIII, № 625, 7 de Octubre 1921. 
Por un lado, estas imágenes darían respuesta a la demanda de un comitente, no serían la puesta azarosa de un fotógrafo, las motivaría la voluntad de ser consumidas de una manera más eficaz y directa. Por otro lado, también, instalarían el deseo de poseer la novedad y, así, activarían el instinto de rivalidad que pretendía persuadir una determinada actitud de aceptación o comportamiento mimético frente a la propuesta.

Roland Barthes postula que la fotografía de moda suele retratar al mundo como si fuera un teatro, con decorado, fondo o escena, todo versa sobre un tema $\mathrm{y}$, a partir de allí, se dan las asociaciones de ideas (Barthes, 2003). De hecho, para cada producción se proyectaba una presentación con un argumento rector de la colección o la línea. En ese decorado significante vivía la mujer y su vestido pero de una manera particular, la premisa era mostrar el objeto en todo su esplendor, volverlo irresistible y reducir la realidad a una "fantasía colectiva," según Ducros (1998) o crear una "realidad perfeccionada." en palabras de Goffman (1988). ${ }^{14}$

\footnotetext{
${ }^{14}$ Haciendo la transferencia del pensamiento de Dubois (1994), en las diferentes fases de lo que él llama "modos de producción", el fotógrafo cuenta con ciertas prerrogativas para que lo fotografiado parezca más atractivo que en la vida cotidiana. En primer lugar, puede predecir o diseñar el resultado que pretende, así como el artista boceta su proyecto. Prepara las sesiones fotográficas, dispone de los personajes y los objetos con anticipación al momento de la toma y puede ejercer sobre ellos procedimientos de manipulación para provocar determinada apariencia. Se vale del maquillaje y la pose, de juegos de iluminaciones para dar luces o sombras, acentuar ángulos, corregir líneas faciales o aportar un aura de mayor encanto. Junto con esto, son estratégicos los dispositivos técnicos, como la calidad de la película, la elección de lentes difusores y los ángulos de toma. En las fases del revelado, los manejos de la película, los retoques hechos a mano, entre otras cosas, concluyen por dar el acabado con el impacto visual más o menos fiel al proyecto original. Esta postura se complementa con las reflexiones de Roland Barthes (1995:16) acerca de la connotación de la fotografía a partir de diferentes niveles de producción o técnicas, unos que modifican la imagen, es decir el mensaje denotado, como el trucaje, la pose de los personajes y la disposición de los objetos; otros que se relacionan con la composición: la fotogenia, el esteticismo y la sintaxis.
} 
La modelo no escapaba al montaje y prestaba sus servicios a los mecanismos sistematizados de las representaciones sociales en tanto reguladores de ciertos mandatos. Según señala John Pultz "al presentar el cuerpo de las mujeres como objeto estético, todas estas fotografías reproducen acríticamente la ideología de su tiempo (Pultz, 2003:49). No es casual que se exhortara "andar un largo camino de sacrificios" para oficiar como modelo, padeciendo intimidaciones y presiones para mantener un estado físico que no estaba al alcance de todas las mujeres:

la figura tiene que exhibir proporciones justas, conocer el secreto del andar distinguido, ser amable y poseer el don de captarse las simpatías de numeroso y selecto público que a diario puebla las tiendas de la aristocracia. ${ }^{15}$

Se deduce que la imagen del cuerpo es tan importante como el cuerpo mismo; debe ser su reflejo. La apariencia que resulta de la fotografía es tan crucial que justifica exigencias anatómicas, incluso morales, con el objeto de transferir la estampa de un cuerpo que valga la trascendencia. Se instaba la continuidad de un plan de alimentación con el fin de evitar el "crecimiento de las carnes", impedir la delgadez excesiva y conservar la frescura de la tez. Esa fisonomía se volvía un referente que exaltaba el carácter estético y demandaba su perfección, incluso y del mismo modo que en otras dimensiones de la vida social, se aplicaba el rigor de carácter punitivo para que las exigencias se cumplieran. ${ }^{16}$

Las crónicas marcan que "el modisto cuida sus maniquíes del mismo modo y con análoga solicitud que la que dispensa el jockey a sus caballos favoritos". La equivalencia, poco inocente y

15 ...iPobre maniquí!. Revista Caras y Caretas. Buenos Aires. Año XVII. $\quad N^{\circ} 802$. 14 de febrero 1914.

16 "Existen multas severas, ya sea por violar las exigencias de un horario riguroso, ya por mostrarse displicente para con los compradores, ya por prolongar demasiado las sesiones y sin provecho inmediato, etc." Ibídem. 
ampliamente ofensiva, marca el grado de dominio que se ejercía sobre las midinettes, discurso que se perfila en columnas de moda:

Esas elegantes están acechando el médico, el manicuro, el masajista que debe hacerlas fuertes para poder ser durante muchos años, el maniquí encantador de la fiesta humana. ${ }^{17}$

Es necesario que el maniquí sea un muñeco a todas horas del día, que guarde muy adentro sus dolores, que tenga la sonrisa a flor de labios y la alegría en los ojos, aun cuando las brutalidades de la vida hagan presa de su espíritu. ${ }^{18}$

Las citas evocan que la modelo era la representación de una estructura corporal bella que proporcionaba un rostro y una anatomía sobre la cual la indumentaria conquistaba sus formas. También, se sumía en la deshumanización al convertirse en dispositivo visual para traducir un concepto estético. La frivolidad, como una condición del sistema de la moda basado en lo aparente, aprueba el mantenimiento de una fachada impersonal e insensible, aún por sobre los perjuicios atribuidos a la salud física y emocional. Substancia y subjetividad de la fémina eran relegadas en vías de significar novedad. El facsímil que queda como resultado en la fotografía se independiza de la identidad femenina que evoca, todo se resume al anonimato de un cuerpo genérico virtualmente imitable.

En consonancia con lo dicho, se sigue un código proxémico particular. Cuando las fotografías mostraban variaciones en la pose frontal o en la llamada tres cuartos, se decidían posiciones pre-moldeadas que aseguraban ciertas inclinaciones, quiebres graciosos y escorzos nada habituales para subrayar determinados detalles. Se regulariza la manifestación de las extremidades que se separan del tronco en actitudes que resultaban burlescas, como

\footnotetext{
${ }^{17}$ La fiesta de la Moda. Revista Plus Ultra. Buenos Aires, Año VIII, n 85, mayo 1923.

${ }^{18}$ Plus Ultra en Viena. La elegancia en la noche. Revista Plus Ultra. Buenos Aires, Año VIII, nº 85, mayo 1923.
} 
recortes de una danza infantil. Se tiene la sensación de que ponen en situación de ridiculez a la actuante, sin embargo, se interpretan como elementos de "las reglas de producción escénica" (Goffman, 1988). En las expresiones faciales había una variada gama de transiciones y la tendencia era mostrar un lenguaje mesurado. La boca y los ojos asumían mayor protagonismo. La sonrisa, en general, distaba de ser estridente, no se daban con frecuencia las muecas desvergonzadas, más bien rictus de labios entreabiertos con discreción. (Imagen 5)
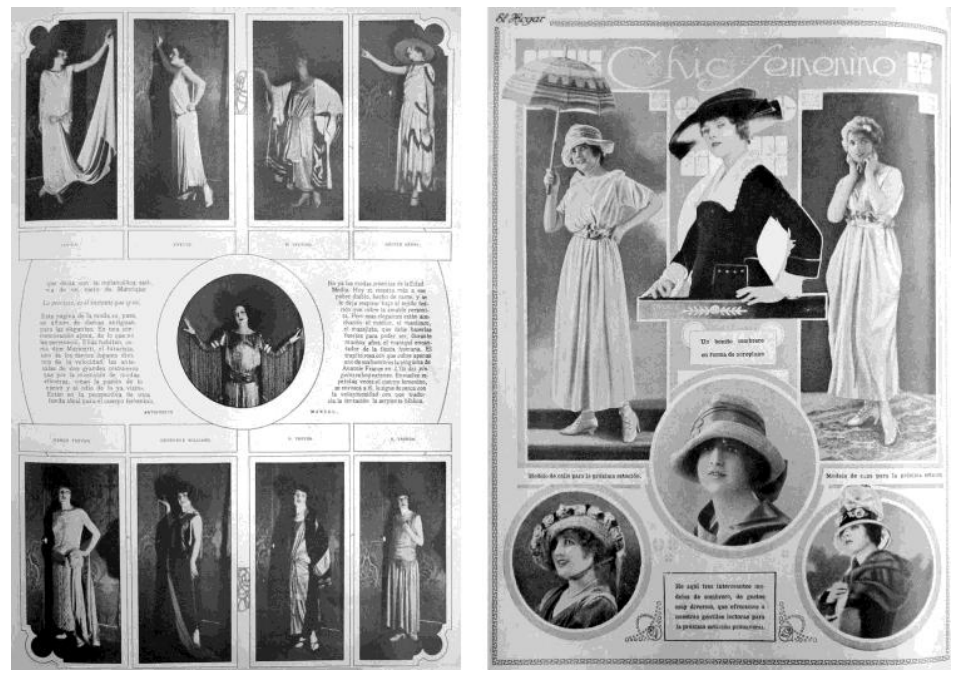

Imagen 5: La fiesta de la moda. Revista Plus Ultra, Buenos Aires, año VIII, no 85, mayo 1923 / El Chic femenino. Revista El Hogar, Buenos Aires, año XVIII, nº 605, 6 de mayo 1921.

Mantener un semblante de circunspección reforzaba la apariencia de una expresión sentimental dosificada. La mirada podía confinarse al campo de la escena fotografiada, la modelo observaba hacia un punto fijo del escenario montado para la toma. Las cabezas se inclinaban hacia abajo, a modo de actitud sumisa; alzaban la vista con gesto de ilusión o apuntaban con 
nostalgia hacia un sitio lejano en el frente. Otras miradas quebraban el universo cerrado de la ficción al marcar un fuera de campo y la presencia de un sujeto externo en la enunciación, persuadiendo, de una manera más directa al observador (Dubois, 1994).

Al cruzar series fotográficas con figurines ilustrados se crea un sentido ambivalente: no se sabe hasta qué punto el figurín cedió sus formas al cuerpo humano o el cuerpo inspiró las formas del figurín. Las tácticas de la publicidad y de la fotografía mantenían puntos de diálogo, por lo cual ilustración de grafito y maniquí de carne y hueso responden a una voluntad de sistematización difícil de soslayar. (Imagen 6)
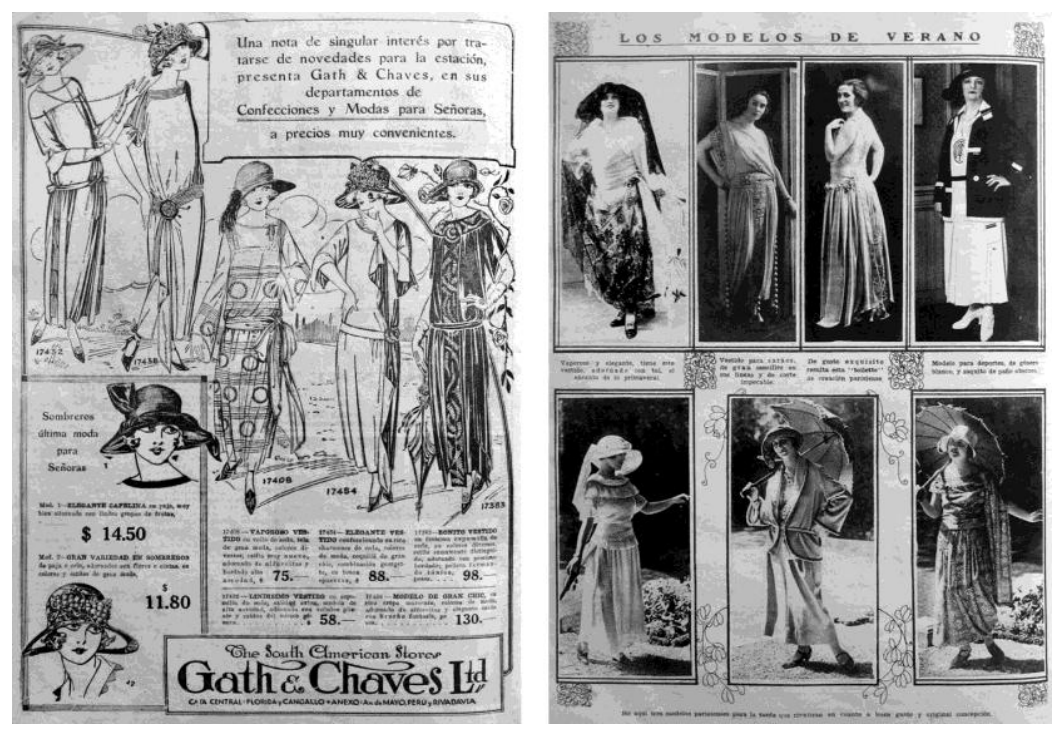

Imagen 6: Aviso de la Tienda Gath y Chaves / Los modelos de verano. Revista El Hogar, Buenos Aires, Año XIX, n 679, 20 de octubre 1922.

Los cuerpos fotografiados no dejan de presentar una ambigüedad que las propias consumidoras de las imágenes advertían: "los maniquíes son, sin excepción, siluetas muy esbeltas, que adoptan 'poses' estudiadas, en un ambiente especial; 
fuera de ese marco resultarían incomprensibles." 19 Sin embargo, en un punto, también eran vistas como ideales a seguir porque, a pesar del grado de ficción y glamour que suponía el mundo del modelaje, las proporciones no distaban demasiado de las que se pretendían para las propias usuarias:

La estética de la moda de esta línea es maravillosa: pero sólo el encanto grácil y caprichoso propio de una mujer joven y esbelta puede obtener el efecto deseado y por eso las bellezas maduras deben abstenerse de ella. ${ }^{20}$

Como derivación, para las lectoras de las revistas, la técnica satisfacía por su aparente autenticidad y, en este sentido, ofrecía ventajas respecto a las imágenes sintéticas:

Mejor que el dibujo es la fotografía. La mujer retratada es la realidad en las proporciones, en la "pose" y sobre todo, es realidad en la brevedad entre las dos horizontales: pecho y bacinete, brevedad muy perjudicial en la estética, la cual está tanto más aventajada cuanto mayor es la distancia, como pasa en los dibujos. ${ }^{21}$

Ya no se trataba de bocetos o grabados, técnicas de uso reiterado desde la aparición de las revistas. Las maniquíes aportaban la imagen de un cuerpo con la misma materialidad que las lectoras. Entre sus imaginarios, se pensaba que venían a saldar las falencias de los figurines ilustrados y que las modas podían ser interpretadas con ciertos grados de "verdad".

En este sentido, además de testimoniar iconográficamente los cánones del gusto, las modelos transferían la conformidad por reivindicar estereotipos ligados a condiciones culturales y sexuales a veces legitimadas, otras no tanto. Puede pensarse en cómo la

${ }^{19}$ La ilusión en la moda. Revista Caras y Caretas. Buenos Aires, Año XXVIII, N ${ }^{\circ}$ 1116, 21 de noviembre 1925.

${ }^{20}$ Plus Ultra en Viena. La elegancia en la noche. Revista Plus Ultra. Op. Cit.

${ }^{21}$ La ilusión en la moda. Revista Caras y Caretas. Op. Cit. 
esbeltez, representada en el plano físico a través de siluetas altas y delgadas, podía invocar, en el plano simbólico, atributos asociados a la fragilidad femenina y consolidar, por este medio, imaginarios negativos sobre el "sexo débil." De algún modo, la construcción social del cuerpo hacia las primeras décadas del siglo XX, contribuía con justificativos que promulgaban ciertas actitudes excluyentes frente a la posibilidad de actuación de las mujeres. Minimizar su participación en lo público, afianzar su rol como objeto al cual contemplar, más interesadas en las vanidades del arreglo personal que en los asuntos de alcance político, eran premisas latentes. La imagen participaba en la elaboración de metáforas visuales para difundir y socializar estos conceptos.

\section{Referentes de moda desde el cinematógrafo}

¿Qué sucede cuando un cuerpo deja de ser anónimo, cuando la fotografía está acompañada por un epígrafe que invoca un nombre y a quién corresponde esa apariencia? La idea de vaguedad se disipa. La identidad femenina se inviste de las cualidades que proceden de ese cuerpo y se pone en juego una relación particular con la idea de índex. La proximidad entre el signo y su objeto se vuelve identificación integral: evoca a ese cuerpo de existencia física singular.

Un caso recurrente hacia la década de 1920 fue la presencia de las estrellas de cine. El beneficio era mutuo, mientras los modistos exhibían sus artículos para seducir a nuevas clientas, las stars difundían su imagen y con ello podían obtener beneficios para su crecimiento profesional. Si se reflexiona sobre el proceso de emulación, la atribución a una semejanza directa conlleva a que no se cuestione al referente, éste existía $y$, además, era exitoso. Las subjetividades no quedaban despojadas, todo lo contrario, los rasgos personales podían transferir determinado sentido como audacia, distinción, modernidad.

El desarrollo del cine concibió que imágenes fijas se pusieran en movimiento. Si la fotografía en sí misma era entendida como la 
ratificación visible de un acontecimiento, el cine lo potenció (Tuñon, 2003). En los primeros tiempos, permitió el conocimiento de objetos y paisajes lejanos, la recreación de sucesos históricos, incorporó la narración de ficción y se constituyó en un medio de expresión para el entretenimiento y el ocio totalmente novedoso. Estas imágenes "crearon un depósito de visiones del mundo, de alegorías de la sociedad y de íconos populares que compendiaron el siglo XX" (Benet, 2004:14). Se convirtió en una tecnología dominante de la cultura visual que mediaba y fijaba sensibilidades e imaginarios, en la cual no se sabía muy bien dónde empezaba la realidad, dónde la representación y dónde la ilusión (Metz, 1973).

El éxito de las industrias europea y norteamericana, especialmente de Hollywood, junto a la capacidad de reproducción mecánica, impulsaron la circulación vertiginosa de las imágenes de actrices y actores a públicos diversos. Se valieron de variados medios de comunicación, entre ellos, la prensa gráfica para informar acerca de los argumentos, los personajes y los chismes que intervenían en la construcción de las celebridades. En las revistas ilustradas argentinas se incluyeron tópicos con reportajes, biografías y fotografías, de modo que las figuras no quedaran confinadas a los momentos de exhibición en las salas y la multiplicación de su imagen, lejos de desvalorizarlas aumentaba su valor, las volvía más deseables (Morin, 1964).

Si en el plano de la representación el cine contribuyó con diferentes estereotipos de mujer-heroína, creó, al mismo tiempo, un nuevo modelo de impacto social encarnado en la propia figura de la star renovando el elenco de imaginarios "divinizados." 22 Según Gubern "las razones psicológicas más profundas del arraigo del star system están en la 'transferencia emotiva' que se opera en el espectador durante el ritual de la proyección cinematográfica" (Gubern, 2001:100). No importa la distancia real y simbólica del

\footnotetext{
${ }^{22}$ No se pretende introducir en este texto discusión acerca de los estereotipos femeninos planteados en el cine. Para ello pueden verse Morin (1964); Kaplan (1998); Amado (2000); Aumont, Bergala, Marie, Vernet (2005); Kuhn (1991); Laguarda, (2006).
} 
público en relación con la celebridad, la "transferibilidad" hacía posible la referencia del arquetipo ideal, ese que encarnó el personaje a una persona corriente. Eran mujeres imaginarias que se figuraban como realidad por el deseo de las espectadoras, sus comportamientos originados en el medio de la ficción, se volvían opciones para la vida. Es que ellas eran construidas en esa misma realidad y la realidad se alimenta, también, a través de lo imaginario (Morín, 1964).

Hacia 1919, Horacio Quiroga, reconocido escritor argentino, bajo la firma de "el esposo de Dorothy Phillips" se preguntó el por qué del particular encanto de las estrellas y el profundo amor que despertaban. La razón, opinaba, es que la estrella de cine daba su atracción sin medida de tiempo y todo en ella era inquietante: ojos, boca, frescura, sensibilidad, los impulsos apasionados. Adoptar su apariencia significaba apropiarse, inconscientemente, del andamiaje simbólico incluso mágico que encubría a la figura y, al hacerlo propio, alcanzar distinción y asumir sus aptitudes por asociación.

Así, las "imágenes vivas" se convirtieron en una influencia de modelos culturales que se irradiaban en diferentes ámbitos. Como era de suponer, asumieron un papel relevante en relación con las modas: "ya es sabido que la moda tiene un palacio legislativo desde el que se dictan sus decretos inapelables y con inmediata fuerza obligatoria (...) es la escena y la encargada de promulgar las leyes, actrices de primera línea" ${ }^{23}$, se proclama en la revisa madrileña La Esfera.

El cuerpo se convirtió en un punto clave de atención que coligaba de una manera directa el valor del aspecto físico con el lugar de gloria:

Su bonita silueta, de líneas casi perfectas, no podía pasar inadvertida para un director que (...) sabe cuánto vale una mujer bonita. (...)Y como lo que quiere una bella

${ }^{23}$ La moda y las actrices francesas. Revista La Esfera. Madrid, Año I, № 11, 14 de marzo 1914. 
mujer generalmente lo consigue, Marie debutó al fin como actriz estrella. ${ }^{24}$

...su belleza irreprochable fue el factor decisivo en su rápida ascensión hasta la categoría de estrella absoluta (...) Pero los yanquis no quieren mujeres bonitas exclusivamente y miss Fair debió desarrollar evidentes aptitudes artísticas. ${ }^{25}$

Si bien es cierto que se elogiaba el lado profesional, no podía eludirse el rol capital de la hermosura y el charm como estimulantes.

No cabe duda que las imágenes se trucaban a favor del embellecimiento, del mismo modo que se hacía con las modelos en las tomas fotográficas. A fuerza de cosméticos, afeites y postizos hacían posible el resto de la transmutación para "adulterar" al personaje:

la tez (...) no se conoce nunca sin la pomada amarilla $-e l$ "insecticide powder"- (...) las dentaduras imperfectas y aun simplemente medianas ceden el puesto a magníficas hileras de dientes postizos que (...) no pertenecen a sus propietarios más que "por haberles costado su dinero". ${ }^{26}$

Revistas especializadas, como Moving Picture Stories, revelaban los secretos de esas fisonomías y advertían que si se encontraban casualmente con un ídolo cinematográfico, era muy probable que éste les resultare más vulgar, menos atrayente y pasara completamente inadvertido.

El vestuario ${ }^{27}$ formaba parte del glamour y ayudaba a reforzar la personalidad de estrella. Lo que lucía le otorgaba su sello de identidad y distinción, el ser fuera de lo común (Mazziotti,

${ }^{24}$ Teatro del silencio. Revista Caras y Caretas. Buenos Aires, Año XXIX, No 1463, 16 de octubre 1926.

${ }^{25}$ Album de artistas. Revista Caras y Caretas. Buenos Aires, Año XXIX, No 1459 , 16 de septiembre 1926.

${ }^{26}$ Ibídem.

${ }^{27}$ Para ampliar sobre el tema confróntese Calefato (2001:213-224). 
2001). Se permitía la asimilación de un estilo corporal íntegro: una manera de llevar la indumentaria, un corte de pelo, maquillaje, un lenguaje en el andar, gracia en los gestos y las expresiones. Las stars pusieron en escena un estilo de vida que sintetizaba las aspiraciones de la mujer urbana y moderna que ensayaba dosis de emancipación. El fenómeno sociopolítico que acontecía hacia los años '20, tendiente a la conquista de cierta autonomía, encontraba en las figuras del cine un escenario visualmente eficaz donde encarnar $y$ difundirse. Podían asumir actitudes atrevidas $y$ fisonomías controversiales que quedaban avaladas por la fama, capaces de interpelar los roles ansiados y rechazar las falsas hipocresías que, a su criterio, hacían ver ridículas a las mujeres de su tiempo.

Una de las consecuencias fue la promulgación de una nueva moral sexual. Dora Barrancos postula que la subjetividad femenina estaba en un tiempo de tránsito al acontecimiento del deseo, mientras pesaban las obligaciones y los estereotipos (Barrancos, 1999). Entonces, a través del cine, se vivificó la ilusión de una dimensión de rescates en el orden corporal y del dominio del placer. El estereotipo de femme fatal, divorciada de la discreción, se desplegaba en la dimensión de lo irreal, jugaba con la lujuria y la malevolencia, añadía rasgos de picardía en cuerpos extrovertidos que interactuaban entre sí, con ropas que cubrían menos de lo que hubieran querido los moralistas de la época. Por estas razones, no tardaría en instalarse la inquietud por perturbar la moral como uno de los temas en discusión. Las damas católicas del Círculo de la Prensa de Buenos Aires se pronunciaron ante la situación $y$, en relación con esto, en la revista Cinema Star se señaló:

Esto de vestir el desnudo, es decir, del uso incondicional de la "hoja de parra", no es, como muchos suponen el único medio de moralizar. (...) siendo el cinematógrafo en la mayoría de los casos una copia fiel de la realidad, no hace más que reproducir las imágenes que la vida le presta, sin 
añadirles nada de su parte, como es ley en los apergaminados comentadores. (...) hay inmoralidad en el mundo, cosa que prueba el cine (...) la generalización de la hoja de parra ha vuelto inmoral a todo lo que tapa... ${ }^{28}$

Entre las iniciativas, las compañías productoras debían cuidar el contenido de los argumentos. Había censores encargados de examinar las películas antes de exponerlas al público, a fin de evitar que se proyectaran asuntos contra el decoro, la religión y las instituciones. $^{29}$ En cada programa debía incluirse algo que permitiera al espectador "acercarse a la perfección moral", para que de ellos se derivaran buenas enseñanzas.

Esto no prohibia, en las imágenes de moda, la articulación de una estética con mayor sofisticación y sensualidad, incluso en la composición gráfica de las secciones donde estas se incluían. ${ }^{30}$ Basta con detenerse en las pequeñas figuras que se diseminaban en las páginas del "chic femenino" para ver cómo se provocan situaciones de carga erótica entre las féminas, dando a ver cuerpos ávidos de hedonismo. Las imágenes ponen en evidencia la sincronía entre lo que se daba en el plano del cinematógrafo y la estética que se adopta en las fotografías de moda (Imagen 7).

${ }^{28}$ La moralidad en la pantalla. Revista Cinema Star. Rosario, Año V, № 183, 30 de septiembre 1922.

${ }^{29}$ El cinematógrafo se populariza. Revista El Hogar. Buenos Aires, Año XII, № 292, 7 de mayo 1915.

${ }^{30}$ No se puede pasar por alto que los montajes fotográficos celebran figuras al estilo de una ilustración de Erté, George Barbier o George Lepage, artistas de la vanguardia artística que tenían una estrecha vinculación con el sistema de la moda pues creaban figurines y sus ilustraciones se publicaban en las revista Vogue y Harper's Bazaar. A esto se sumaba la influencia de los Ballets Rusos, primero, dirigidos por Diaghilev y hacia mediados de los años '20 el estilo de la bailarina Josephine Baker, reconocida por sus danzas innovadoras del jazz con falda de plumas, torso semidesnudo y exuberancia de accesorios recubiertos en strass y perlas. Cfr. Lehnert (2000). 

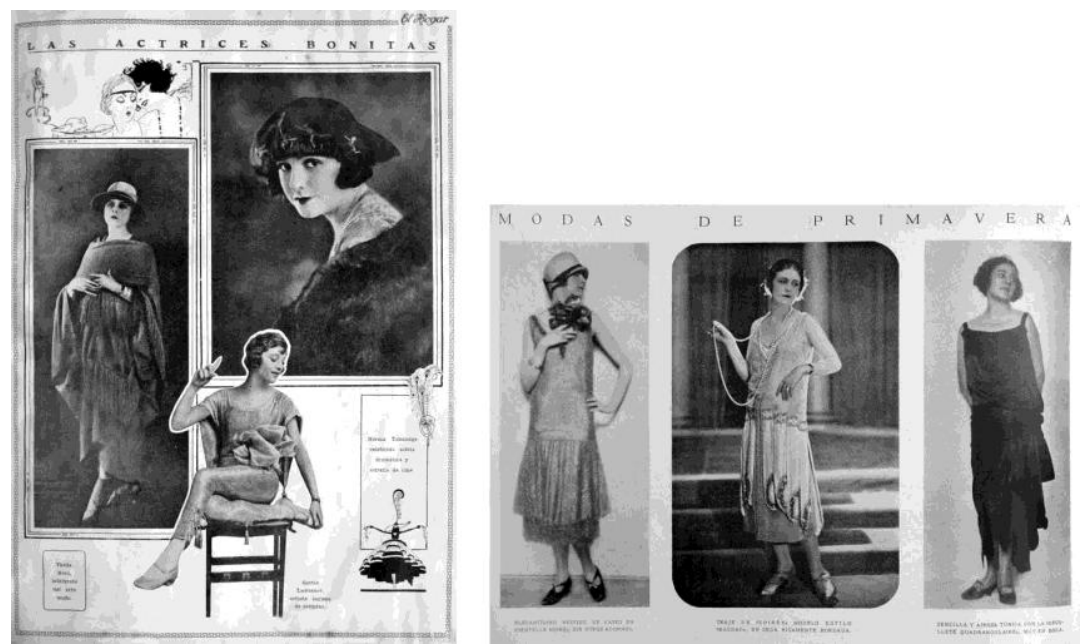

Imagen 7: - Cine -Las actrices bonitas. Revista El Hogar, Buenos Aires, año XVIII, n 594, 25 de febrero 1921 / - Moda - Modas de primavera. Revista Plus Ultra, Buenos Aires, año X, n 114, octubre 1925.

Resulta sugestiva la extendida aparición de las stars difundiendo los diseños de trajes de baño de vanguardia. Así como se las retrataba en escenas al aire libre, practicando deportes y fumando en público, lucir una silueta despojada de prejuicios decimonónicos era un emblema más de superación. Vale recordar que hacia los '20 vestir un maillot era una práctica que todavía distaba de ser aceptada sin conflictos y, desde las representaciones sociales, se asociaba con la exaltación del pudor y la provocación de la curiosidad masculina (Kaczan, en prensa). Ahora, la misma apariencia ejercida por la estrella tenía otra connotación, la actitud del cuerpo lo confirma, ellas alardean su belleza (Imagen 8). 


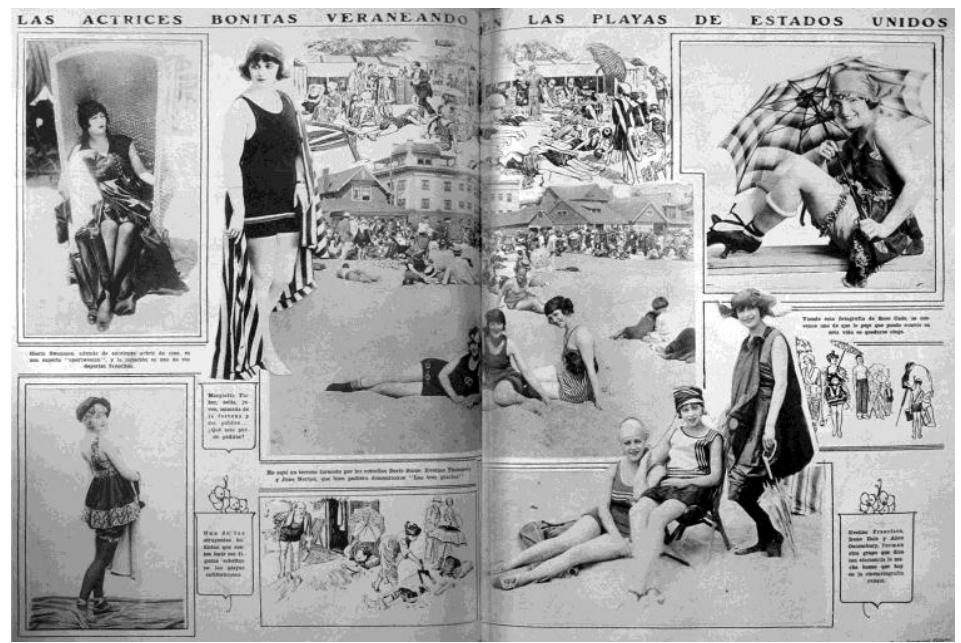

Imagen 8: Las actrices bonitas veraneando en las playas de Estados Unidos. Revista El Hogar, Buenos Aires, año XIX, n692, 19 de enero 1923.

No es casual que los diseñadores las eligieran para mostrar las extravagancias de sus creaciones debido a la licencia que les garantizaba un lugar de renombre público y, en su generalidad, a la posesión de cuerpos privilegiados. En contraposición, las mujeres distinguidas no aparecían ostentando su cuerpo en la playa, se valían de los pantalones pijamas para resguardarse con pretextos de discreción.

\section{Fotografías y retratos}

La tecnología asistió el protagonismo del close up y esto produjo una inclusión decisiva en las formas de percepción del diseño editorial. Se tradujo en la toma fotográfica, en los avisos publicitarios, en las tapas de las revistas, se abusó del retrato. Se difundió un semblante de ojos delineados con tupidas pestañas; bocas pequeñas, carnosas y de color carmín. No se trataba de 
rostros atemporales, al contrario, eran los prototipos de los primeros planos de Hollywood.

Los retratos irradiaban un magnetismo que vacilaba entre la inocencia y la perdición, los trucos ópticos se perfilaron a su favor. La composición plástica modeló la luz con una mayor gama de valores, acentuando los ojos y los labios, dos elementos de fuerte carga simbólico-erótica. Es coherente que los ojos sean un punto de atracción tan poderoso en un ámbito que despierta sospechas de turbar la moral, "los ojos hablan las distancias del pudor" (Sarlo, 1985). El rostro adquirió un lugar trascendental, si se piensa en el cine mudo, el rostro condensaba todas las expresiones, las que debían ser canalizadas por una voz que estaba ausente.

La industria cosmética permitió que la ilusión de una tipología facial de moda llegara a las mujeres corrientes. Los avisos de afeite abastecieron nuevos productos para lograr ojos más profundos y brillantes y para resaltar bocas de "expresión irresistible" a través de lápices de labios (Imagen 9).

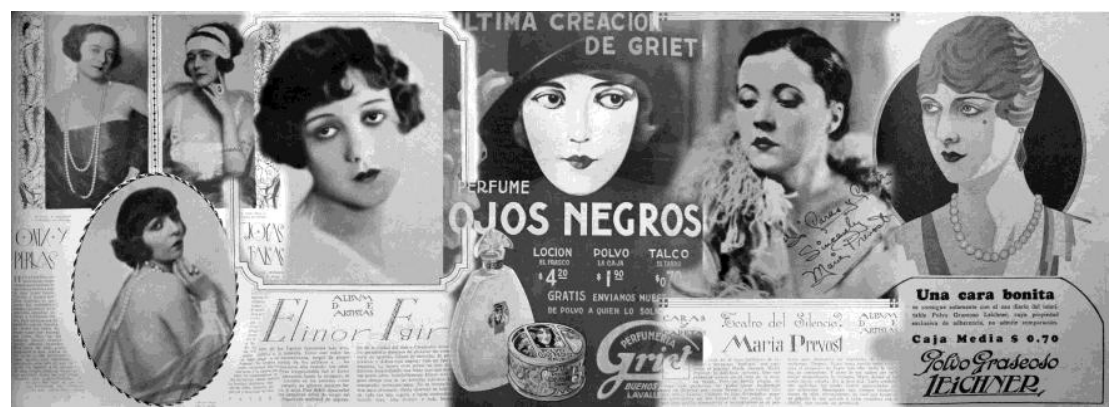

Imagen 9: Composición de la autora entre -Moda- Onix y Perlas. Joyas falsas. Revista Plus Ultra. Buenos Aires, año X, n 110, junio 1925-CineAlbum de artistas. Revista Caras y Caretas, Buenos Aires, año XXIX n ${ }^{\circ}$ 1459, 16 de septiembre 1926 / -Aviso- Aviso Ojos Negros. Revista Caras y Caretas, Buenos Aires, año XXIX, no 1429, 20 de febrero 1927 / Cine-Teatro del silencio. Revista Caras y Caretas, Buenos Aires, año XXIX, no 1463, 16 de octubre 1926 / -Aviso- Aviso de Leichner. Revista Caras y Caretas, año XXXI, n 1574, 10 de diciembre 1928. 
Así como en el inicio se sugirió la relación entre retratos y fotografías de moda, con el correr de los años, la influencia se daría en forma inversa. Las convenciones de puesta en escena, las técnicas de iluminación, el estilo del maquillaje y la postura, propios del lenguaje fotográfico, se volcaron a la composición de los retratos (Imagen 10). En una fotografía con retoques de color en las mejillas y los labios, una mujer aristocrática posa como las mannequins vivants. Está despojada de cualquier ademán gracioso, el porte recatado se asocia con su linaje selecto. El halo de luz que contornea la figura en la imagen contigua llena de misticismo y evidencia el uso de lentes difusores y efectos de iluminación tan empleados en las formas de comunicar las modas. ${ }^{31}$

31 La práctica del retrato fotográfico artístico se fue haciendo cada vez más frecuente. Se alentaba el registro de este tipo de imágenes para "la mejor conmemoración", como "recuerdo de una fecha feliz". El objetivo se anclaba en no disminuir la belleza: Es un deber para con usted misma perpetuar en su retrato su punto de vista más favorable, su expresión más bella y personal.(...) La representación fría de un aspecto cualquiera de la realidad no debe satisfacer sus exigencias (...) Bixio \& Castiglioni descubrirán todos los detalles que deben concurrir a que su fotografía la represente tal cual es usted el día en que está más hermosa. Es indudable que aunque el personaje retratado no tenga alcance masivo, aunque su imagen no circule en medios gráficos como en una revista, la fisonomía agradable era la clave para viabilizar una personalidad distinguida que conlleve su satisfacción personal y la construcción de un aspecto que merezca el respeto de los otros. Aviso de la casa fotográfica Bixio \& Castiglioni. Revista Caras y Caretas. Buenos Aires, año XXV, n 1265, 30 de diciembre 1922. 

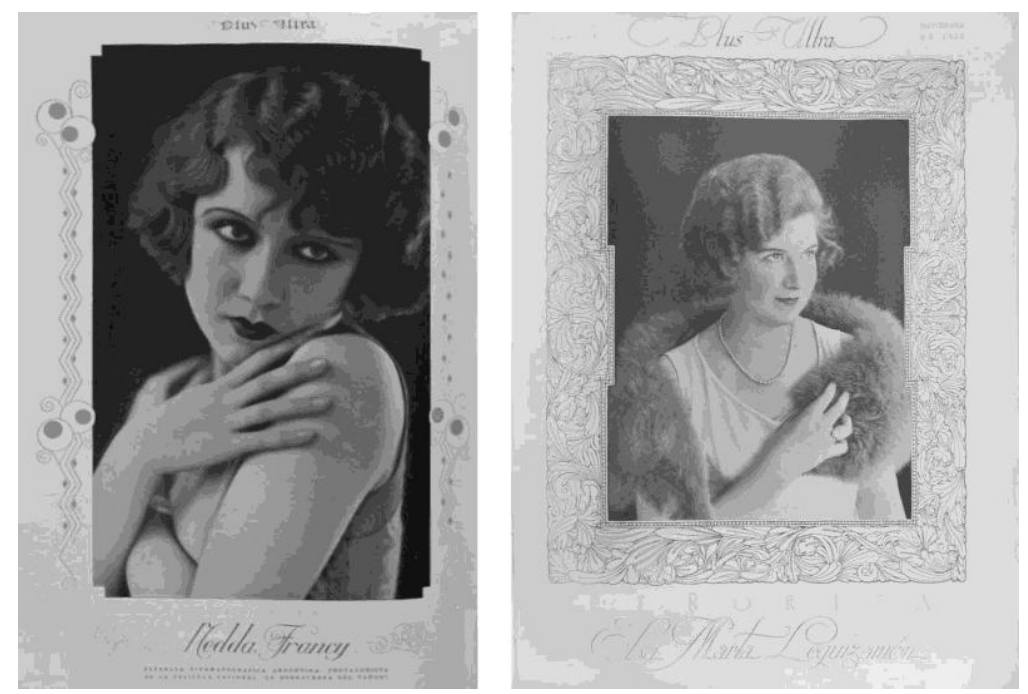

Imagen 10: Composición de la autora entre -Retrato-Siluetas Aristocráticas. Revista Caras y Caretas, Buenos Aires, año XXVIII, $\mathrm{n}^{\circ}$ 1412, 24 de octubre 1925 /-Fotografía Moda- Modelo de Paris. Revista Caras y Caretas, Buenos Aires, año XXIX, n 1466, 6 de noviembre 1926 / -Retrato-Actualidades gráficas. Revista El Hogar Buenos Aires, año XVIII, nº 627, 21 de octubre 1921.

Si bien las actrices "modelan la nueva clase de belleza" (Paris, 1989:132) es inevitable que no sea adoptada del mismo modo por todas. Los retratos fotográficos en las páginas sociales de las señoritas de elite, de las que se hizo mención líneas arriba, adoptaban ciertos atributos de la apariencia pero con limitaciones. Naturalmente y como ya se ha visto, este tipo transgresor despertaba intranquilidad en los grupos devotos del patriarcado. Los comportamientos de la mujer con atributos propios de los "vicios de la modernidad" formaban una amenaza para las argentinas decentes que contribuía con la desestabilización de un estereotipo nacional socialmente controlado. Se reconoce que el grado de excentricidad era menor, los grupos de elite buscan ser más refinados con actitudes poco provocativas. La distinción con 
recato sigue en la línea de la mujer que quiere verse moderna pero que no pone en crisis los roles largamente sobrevaluados. Primaba el estar al margen de expresiones de moralidad licenciosa que pudieran provenir de la apariencia de una $\operatorname{star}^{32}$ (Imagen 11).

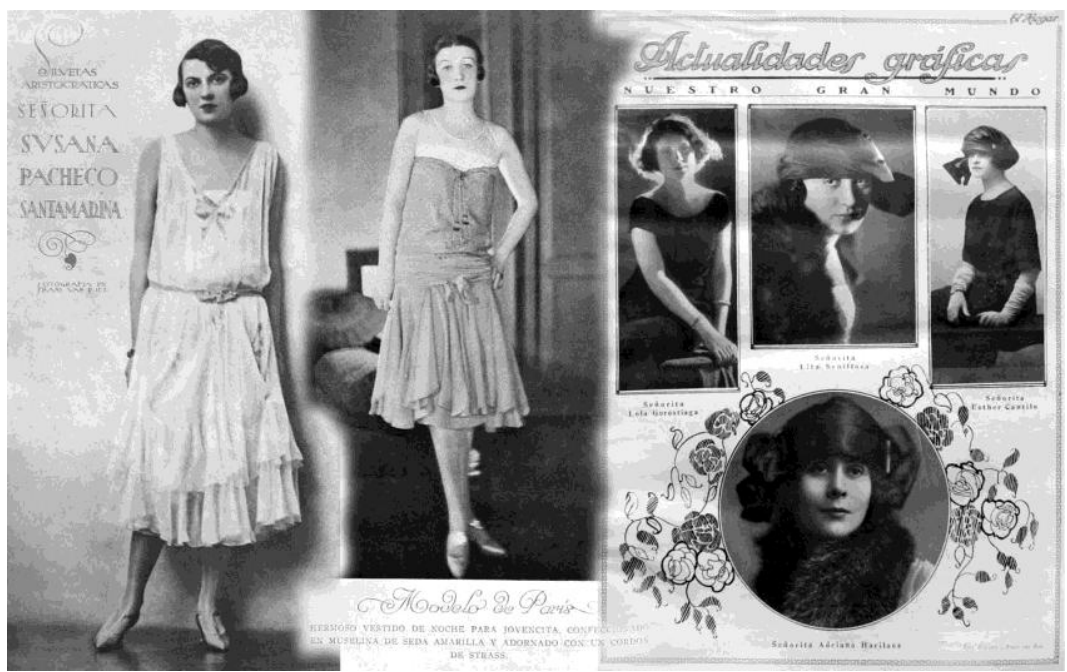

Imagen 11: -Cine- Señorita Medda Francy. Revista Plus Ultra, Buenos Aires, año 13, n 149, septiembre 1928 / -Retrato- Srita. Elsa Marta Leguizamón. Revista Plus Ultra, Buenos Aires, año X, n 115 , noviembre 1925.

${ }^{32}$ Kathleen Newman analiza la trayectoria de las imágenes femeninas 1916 y 1926 en Caras y Caretas y Plus Ultra para indagar que así como se producen cambios sociales e innovaciones en las formas políticas y culturales del estado argentino, cambia también la preocupación visual de lo que se transmite en relación con el modelo estético femenino. Revela que en los años '16 la imagen de estrellas del cine se emplea para dar idea de la "nueva mujer urbana", mientras que para 1926 éstas son reemplazadas por los retratos de aristócratas jóvenes y elegantes. Según la autora, este síntoma se debe a que la imagen de la mujer con atributos propios de la modernización, para mediados de los años '20, se volvió una amenaza para quienes se valían de la oligarquía y el patriarcado (Newman, 1990:74-88). 
Es oportuno marcar que así como los modelos propuestos por las stars y por las mujeres decorosas parecen, en primera instancia, confrontar imaginarios sobre el tipo de feminidad que cada uno propone, en un punto correlacionan una misma idea. Ambos remiten a estereotipos que asisten las inquietudes masculinas, no hacen más que alimentar argumentos de carácter imperativo que siguen intimando obligaciones derivadas de la condición genérica y que marcan, de ese modo, la permanencia de ciertas representaciones dominantes de acatamiento y docilidad en la cimentación de una feminidad tradicionalmente legitimada.

\section{Algunas reflexiones}

Las fotografías de moda en la prensa ofrecieron la posibilidad de que numerosos y heterogéneos grupos de lectores se aproximaran a las novedades del vestir sin la necesidad de recurrir a revistas especializadas. A la vez que lo hacían, revelaron diferentes aristas.

Por un lado, muchas fotografías mostraban excentricidades, creaciones con formas más vale escultóricas, hacían alarde de un show de lo efímero como activador del consumo. Se trataba de diseñar modelos que se constituían como "enigmáticas pero modernísimas figurillas", como apuntaba una cronista afamada de las vanidades porteñas. Al confrontar las imágenes de revistas consultadas junto a fotografías familiares de archivos privados, se pone de manifiesto que muchas de las propuestas quedaban en la esfera de grupos minoritarios y no llegaban a ser adoptadas de forma análoga en la vida cotidiana. Lo que se detecta es el seguimiento de un estilo general con ajustes de acuerdo a las inclinaciones individuales y a la pertenencia social de la usuaria. En sí mismas, las imágenes difundían conceptos estéticos en respuesta a estilos más amplios del cambio cultural, eso es lo que un público más amplio adoptaba.

Por otro lado, situados en el lugar de reconocimiento de las imágenes, las lectoras percibían que los objetos protagónicos - 
cuerpo e indumentaria - enunciaban la presencia de un original y compensaban la necesidad de hallar en ellos veracidad. La espectadora estaría frente a un cuerpo femenino idealizado y a objetos existentes. Desde ese punto, la fotografía sería condescendiente con su interpretante. Pero, no se puede omitir que, desde los procesos de producción, se ha actuado ex profeso sobre esa escenificación y versan sobre él convenciones y montajes que alteran el significante y sus significados; en realidad, se está en presencia de un original tergiversado. Se ha visto cómo recursos técnicos, maniobras proxémicas, estrategias enmascaradas colaboran en el acento de determinadas facetas de sentido que, en última instancia, hacen del cuerpo un soporte desprovisto de realidad aunque la lectora tenga la sensación de verosimilitud.

En esta dimensión se anclan las imágenes de las maniquíes y de las celebridades que encarnaban la belleza perfecta sin ser, realmente, esa imagen la legítima. Remiten a la subjetividad personal y mucho a la necesidad de sostener un imaginario mediatizado por la graduación de fantasía, perfección y erotismo, poniendo en juego el valor de la feminidad consagrada. Es así que se ratifica la lectura de las imágenes como fenómenos socioculturales que no propone representaciones visuales aisladas sino, también, ideas y conceptos que inducen determinados comportamientos. Son imágenes que condensan estrategias de distinción, lógicas de competencia, móviles de diferenciación social y de gratificación personal que incitarían actuaciones miméticas y de emulación.

Por último, es curioso detectar que los precedentes de moda como podían ser los retratos de la high, y las fotografías de las stars, tan distantes entre sí, por razones analizadas, en un punto se cristalizan: son tan deseadas como inalcanzables. Las primeras por la distancia de pertenencia social, las segundas por su lugar de fama pero, así y todo, en el marco de las representaciones fotográficas, cautivaban el deseo de ser plagiadas. 


\section{Referencias bibliográficas}

AmADO, Ana. La teoría del cine y el marco de la historia. Entrevista a Laura Mulvey. Entrepasados, no 18/19, Buenos Aires, Año IX, 2000, pp.173-181.

ARIZA, Julia. Bellezas impresas: retratos fotográficos de mujeres en la prensa periódica ilustrada de Buenos Aires a comienzos del siglo XX. En publicación electrónica (CD) VI Jornadas Nacionales Espacio, Memoria e Identidad, Rosario, Argentina, 29, 30 de Junio, 1 de Julio, 2011.

Aumont, Jacques; Bergala, Alain; MARIE, Michel y Vernet, Marc. Estética del cine. Buenos Aires, Paidós Comunicación, 2005. . El rostro en el cine. Barcelona, Paidós, 1997.

BARRANCOS, Dora. Moral sexual, sexualidad y mujeres trabajadoras en el período de entreguerras. En: DEVOTO, Fernando y MADERO, Marta. (coord.) Historia de la vida privada en la Argentina, La Argentina entre multitudes y soledades. De los años treinta a la actualidad, Tomo 3. Buenos Aires, Taurus, 1999, pp.199-226.

CEPPI, Ricardo. Sexo-s en el lupanar: un documento fotográfico (circa 1940). Cadernos Pagu (25), Campinas-SP, Núcleo de Estudos de Gênero - Pagu/Unicamp, July/Dec, 2005, pp.357-390.

BARTHES, Roland. La Cámara Lúcida. Barcelona, Paidós, 1994.

. Lo obvio y lo obtuso. Imágenes, gestos, voces. Barcelona, Paidós, 1995.

. Sistema de la moda y otros escritos. Buenos Aires, Paidós, 2003.

BAURET, Gabriel. De la fotografía. Buenos Aires, La marca, 1999.

BERGER, John. Modos de ver. Barcelona, Gustavo Gilli, 2000. Gili, 2007.

; MoHR, Jean. Otra manera de contar. Barcelona, Gustavo

BuRkE, Peter. Visto y no visto. El uso de la imagen como documento histórico. Barcelona, Crítica, 2005. 
Estampas del deseo y del desear

CAlefato, Patricia. El cuerpo vestido, los sentidos y la escritura: entre moda y cine. En: ESCUDERO CHAUVEL, Lucrecia. (coord.) de Signis 1. La Moda. Representaciones e identidad, Publicación de la Federación Latinoamericana de Semiótica. Barcelona, Gedisa, 2001, pp.213-224.

CORONADO, Diego. De la publicación de la fotografía a la fotografía publicada: en torno a los orígenes decimonónicos de la fotografía publicitaria. Revista Latina de Comunicación Social, año/vol. 3, n 302, agosto, 2000, pp.1-7.

CHECEFSKY, Bruce. Photography and Desire: fashion, glamour and pornography. En: PERES, Michel. (ed.) The concise focal encyclopedia of photography. USA, Focal Press, 2008, pp.84-93.

DuBoIS, Philippe. El acto fotográfico. De la Representación a la Recepción. Barcelona, Paidós, 1994.

DuCros, François. The dream of beauty. En: FRIzOT, Michel. (edit.) A New History of Photography. Italy, Könemann, 1998.

FONTCUBERTA, Joan. Fotografía: conceptos y procedimientos. Barcelona, Ed. Gustavo Gili, 1990.

FRIzOT, Michel. (edit.) A New History of Photography. Italy, Könemann, 1998.

FREUND, Gisèle. La fotografía como documento social. Barcelona, Gustavo Gilli, 1993.

GIL LOZANO, Fernanda; PITA, Valeria; INI, M. Gabriela. (coord.) Historia de las mujeres en Argentina. Buenos Aires, Taurus, 2000.

GOFFMAN, Edving. Les moments et leurs hommes, París, Minuit, 1988.

GunTHERT, André. La force de l'évidence. Du style des photographies d'actualité. Bibliothèque nationale de France. En: $<$ http://expositions.bnf.fr/afp/arret/4/index.htm>. Acceso en: 25 jun 2008.

Genevivieve, Fraisse; Perrot, Michelle. Historia de las mujeres. Siglo XIX. Volumen 4, Madrid, Taurus, 2000.

GuBERN, Roman. Historia del Cine. Barcelona, Editorial Lumen, 2001. 
KACZAN, Gisela. Representaciones de cuerpos femeninos vestidos: Códigos visuales en los mecanismos de producción de exclusión, emulación y distinción social. Mar del Plata 1900-1930. Doctorado Interuniversitario de Historia, Facultad de Humanidades, Universidad Nacional de Mar del Plata, Mar del Plata, Argentina, 2011, mimeo.

. Figuras femeninas en la mira. Cuerpos, vestidos, imágenes en las dos primeras décadas del siglo XX. Mora, $n^{\circ}$ 17, Buenos Aires, Argentina. En prensa.

Kaplan, E. Ann. Las mujeres y el cine. A ambos lados de la cámara. Madrid, Cátedra, 1998.

Kossoy, Boris. Fotografía e historia. Buenos Aires, Biblioteca de la mirada, 2001.

KuHN, Annette. Cine de mujeres. Feminismo y cine. Madrid, Cátedra, 1991.

LAGUARDA, Paula. Cine y estudios de género: Imagen, representación e ideología. Notas para un abordaje crítico. Revista La Aljaba, vol. 10, enero/diciembre 2006, pp. 141-156.

LANGFORD, Michael. Story of photography. Great Britain, Focal Press, 1997.

LEHNERT, Gertrud. Historia de la moda del siglo XX. Köneman, Germany, 2000.

LOBATO, Mirta; DAMILAKOU, María; TORNAY, Lizel. Belleza femenina, estética e ideología. Las reinas del trabajo durante el peronismo. Anuario de Estudios Americanos, vol. 61, n 1, 2004, pp.233-277.

MALOSETti COSTA, Laura; GenE, Marcela. (comp.) Impresiones porteñas. Imagen y palabra en la historia cultural de Buenos Aires. Buenos Aires, Edhasa, 2009.

MARESCA, Sylvain. La Photographie, un miroir des sciences sociales. París, L'Harmattan, 1996.

. Les apparences de la vérité. Terrain, $\mathrm{n}^{\circ} 30$, marzo de 1998. En: < http://terrain.revues.org/index3409.html>. Acceso en: 2 nov 2010. 
Estampas del deseo y del desear

MAzZIOTTI, Nora. Ador(n)adas de la cabeza a los pies: el vestuario de las estrellas de cine latinoamericanas de los años 1930 a 1950. En: ESCUDERO CHAUVEL, Lucrecia. (coord.) deSignis 1. La Moda. Representaciones e identidad, Publicación de la Federación Latinoamericana de Semiótica. Barcelona, Gedisa, 2001, pp.225-237.

MORIN, Edgar. Las estrellas del cine. Buenos Aires, Eudeba, 1964.

MOXEY, Keith. Los estudios visuales y el giro icónico. Estudios Visuales: Ensayo, teoría y crítica de la cultura visual y el arte contemporáneo, $n^{\circ}$ 6, Murcia, España, 2009, pp.8-27.

NEWMAN, Kathleen. Modernization of feminity: Argentina (1916-1926). En: AA. VV: Women, Culture and Politics in Latin America. Seminar of feminism and culture in Latin America. Los Angeles, University of California Press, 1990, pp.74-88.

PARIS B. Louise Brooks, París, PUF, 1989.

PERES, Michel. (ed). The concise focal encyclopedia of photography. USA, Focal Press, 2008.

PRIAMO, Luis. Fotografía y vida privada (1870-1930). En: DeVOTO, Fernando y MADERO, Marta. (coord.) Historia de la vida privada en Argentina. La Argentina plural, 1870-1930. Tomo 2, Buenos Aires, Taurus, 1999, pp.275-299.

Detrás del polvo de las fotografías. En: $<$ http://www.avizora.com/publicaciones/reportajes_y_entrevistas/texto s_0002/0035_luis_priamo.htm >. Acceso en: 2 de nov 2010.

PulTZ, John. La fotografía y el cuerpo. Madrid, Akal, 2003.

Rosenblum, Naomi. A world History of Photography. New York, Abbeville Press Publichers, 1997.

SANTA CRUZ, Eduardo. Estrellas en el firmamento nacional. Comunicación y Medios $\mathrm{n}^{\circ} 16,2^{\circ}$ Semestre, Instituto de Comunicación e Imagen, Universidad de Chile, 2005, pp.21-36.

SARLO, Beatriz. El imperio de los sentimientos. Buenos Aires, Norma, 1985.

SCHAEFFER, Jean-Marie. La fotografía. Una imagen precaria. Madrid, Cátedra, 1990. 
SONTAG, Susan. Sobre la fotografía, 4ta reimpresión. Barcelona, Edhasa, 2006.

SORLIN, Pierre. El "siglo" de la imagen analógica. Buenos Aires, Biblioteca de la Mirada, 2004.

TAGG, John. El peso de la representación. Barcelona, Gili, 2005 [1988].

TELL, Verónica. Reproducción fotográfica e impresión fotomecánica: materialidad y apropiación de imágenes a fines del XIX. En: MAlOSETTI COSTA, Laura; GENE, Marcela. (comp.) Impresiones porteñas. Imagen y palabra en la historia cultural de Buenos Aires. Buenos Aires, Edhasa, 2009, pp.141-164.

TRAVERSA, Oscar. Cuerpos de papel. Figuraciones del cuerpo en la prensa 1918-1940. Buenos Aires, Gedisa, 1997.

WARREN, Lynne. (ed.) Encyclopedia of Twentieth-Century Photography. Volume 1 A-F. New York, Routledge, 2006. 